\title{
MASALAH DAN PENANGGULANGAN SEMBURAN GAS PADA PENGEBORAN SUMUR BML-1 DAERAH MUARA LAWAI, KABUPATEN LAHAT, SUMATERA SELATAN
}

\section{PROBLEMS AND SOLVING OF GAS KICK ON BML-1 DRILL HOLE AT MUARA LAWAI, LAHAT AREA, SOUTH SUMATERA}

Oleh:

Hari Prasetya, ludhi Oki Prahesthi, Tarsis A. Dinarna

Pusat Sumber Daya Geologi

JI. Soekarno Hatta No. 444 Bandung

\section{SARI}

Sumur BML-1 merupakan sumur uji potensi GMB (gas metana batubara) di Muara Lawai, Lahat, Provinsi Sumatera Selatan. Pengungkapan potensi GMB ini dilakukan dengan membuat lubang bor secara vertikal hingga kedalaman akhir $504 \mathrm{~m}$. Sumur ini telah menembus satuan batuan yang pada umumnya merupakan perselingan batupasir dan batu lempung dengan beberapa sisipan lapisan batubara. Ketebalan lapisan batubara bervariasi antara $0,5 \mathrm{~m}$ hingga $10,3 \mathrm{~m}$, dengan kandungan gas metana $\left(\mathrm{CH}_{4}\right)$ hingga $86,75 \%$. Selama proses pengeboran terdapat beberapa kendala yang dihadapi, salah satunya adalah terjadinya semburan gas. Gas keluar dari kedalaman $319 \mathrm{~m}$ dan diduga akibat runtuhnya lapisan barubara ke 9 dengan ketebalan $10 \mathrm{~m}$.

Kata kunci: Sumur BML-1, Muara Lawai, semburan gas, GMB

\section{ABSTRACT}

$B M L-1$ is drill hole is a well for exploration of CBM (Coal Bed Methane) gas potential in Muara Lawai, Lahat, South Sumatra Province. Discovery of CBM gas was done by making a hole drilled vertically to a total depth of $504 \mathrm{~m}$. This well encountered the rock units which are generally contain of sandstone and claystone layer with multiple intersect of coal seam. The thickness of the coal seam varies from $0.5 \mathrm{~m}$ to $10.3 \mathrm{~m}$, with methane content $\left(\mathrm{CH}_{4}\right)$ up to $86.75 \%$. During the drilling process, several obstacles were encountered, one of which was a gas kick. Gas came from a depth of $315 \mathrm{~m}$ and was inferired due to the collapsing of 9 th coal seam of $10 \mathrm{~m}$ thick.

Keywords: Well BML-1, Muara Lawai, gas kick, CBM

\section{PENDAHULUAN}

Pengeboran secara sederhana dapat diartikan sebagai suatu kegiatan menembus batuan dengan menggunakan peralatan bor, untuk mendapatkan sampel dan menghasilkan lubang untuk sarana pengujian. Sumur BML-1 berfungsi sebagai sumur pengujian untuk mendapatkan sampel batubara dan data bawah permukaan (sub surface) yang meliputi litologi batuan, formasi batubara serta potensi Gas Metan Batubara (GMB) di daerah Lahat.

Secara administratif letak sumur BML-1 berada di Desa Muara Lawai, Kecamatan Merapi Timur, Kabupaten Lahat, Provinsi Sumatera Selatan atau terletak pada posisi $9595018 \mathrm{E}$ dan $0358959 \mathrm{~S}$ dengan elevasi $59 \mathrm{~m}$ di atas permukaan laut (Gambar 1).

Lokasi sumur ini berjarak sekitar $250 \mathrm{~km}$ ke arah barat daya dari Kota Palembang atau sekitar $20 \mathrm{~km}$ ke arah timur laut dari kota Lahat.

Potensi GMB dunia sangat besar yang tersebar terutama di Rusia, Canada, China, Amerika Serikat, Australia, dan Indonesia di urutan keenam (http://coalbed methane.wordpress.com/tag/potensi/). Beberapa Negara telah sukses memproduksi dan memanfaatkan GMB sebagai bahan bakar yang ramah lingkungan karena telah memanfaatkan gas metana yang merupakan salah satu kandungan gas yang dapat menyebabkan kerusakan lapisan ozon apabila menguap bebas. Selain itu dengan pemanfaatan GMB akan meningkatkan keamanan para pekerja 
pertambangan batubara lapisan dalam karena akan mengurangi kadar metana yang memiliki sifat mudah terbakar dan beracun sehingga mengganggu pernapasan para pekerja pertambangan.

Indonesia sendiri menurut penelitian Advance Resource International Inc. (ARII) bersama dengan Direktorat Jenderal Minyak dan Gas Bumi Kementrian Energi \& Sumber Daya Mineral memiliki potensi GMB sebesar 453 TCF (Trillion Cubic Feet) yang tersebar di sebelas cekungan di Pulau Sumatera, Kalimantan, Jawa dan Sulawesi (http://coalbedmethane.wordpress.com/tag/ potensi/). Potensi besar GMB Indonesia tersebut hampir setara dengan potensi Gas Bumi Indonesia yaitu sebesar 507 TCF dengan cadangan terbukti sebesar 112 TCF. Hasil produk GMB diproyeksikan akan memenuhi kebutuhan sumber energi Indonesia dan menunjang program
Kebijakan Energi Nasional (KEN) yang tertuang dalam Keputusan Presiden No. 5 tahun 2006 dengan fokus meningkatkan sumber energi baru dan terbarukan serta secara bertahap mengurangi penggunaan dan ketergantungan Minyak dan Gas Bumi sebagai sumber energi Indonesia (http://coalbedmethane.wordpress.com/tag/ potensi/).

Sedangkan berdasarkan data Bank Dunia, konsentrasi potensi GMB terbesar terletak di Kalimantan dan Sumatera. Di Kalimantan Timur, antara lain tersebar di Kabupaten Berau dengan kandungan sekitar 8,4 TSCF, Pasir/Asem (3 TSCF), Tarakan (17,5 TSCF), dan Kutai (80,4 TSCF). Kabupaten Barito, Kalimantan Tengah (101,6 TSCF). Sementara itu di Sumatera Tengah (52,5 TSCF), Sumatera Selatan (183 TSCF), dan Bengkulu 3,6 TSCF, sisanya terletak di Jatibarang, Jawa Barat (0,8 TSCF) dan Sulawesi (2 TSCF)

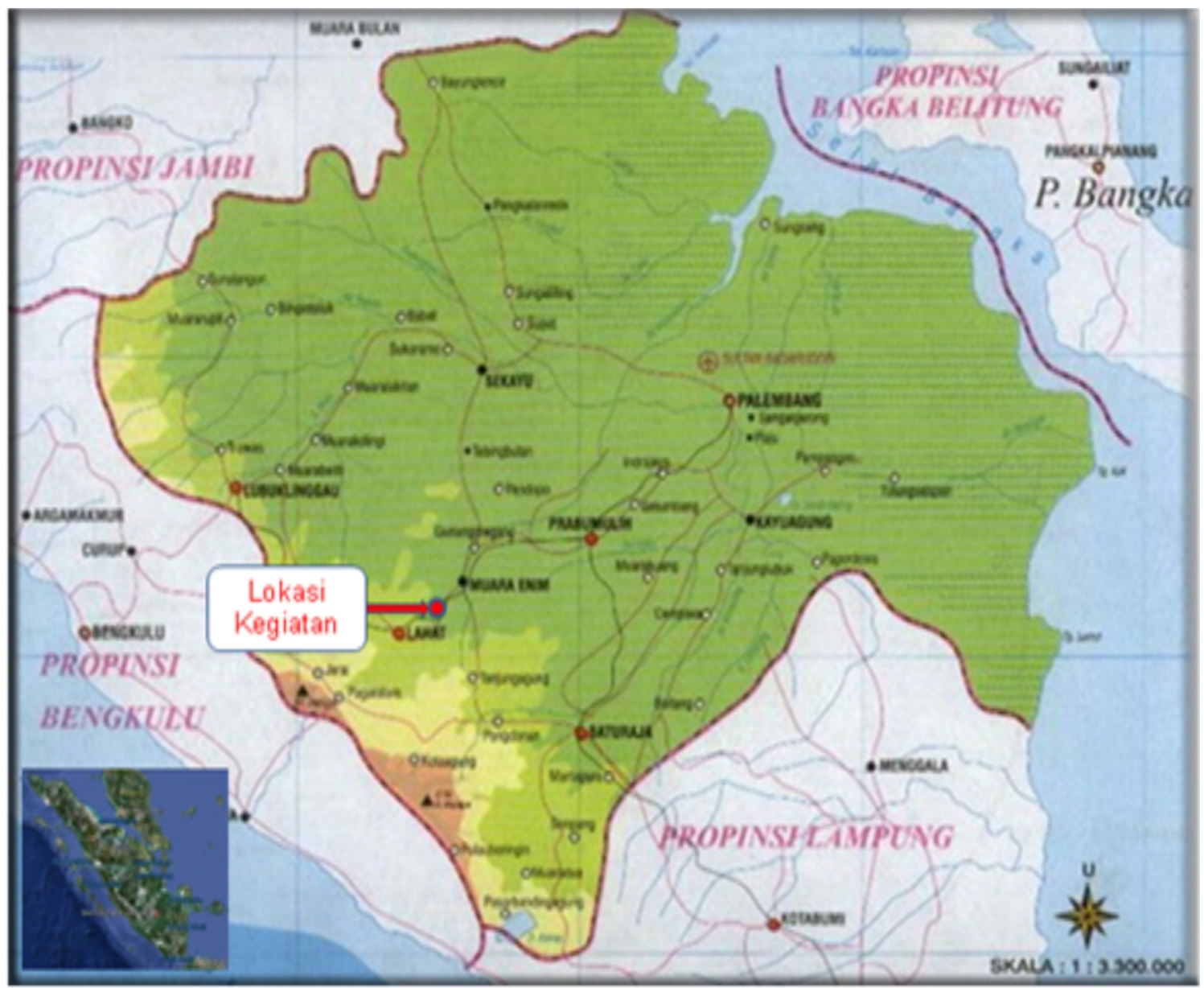

Gambar 1 Peta lokasi kegiatan pengeboran sumur BML-1 Daerah Lahat, Propinsi Sumatera Selatan 
(Kompas on Domu Damians Ambarika - 9 Juni 2008).

Pada tahun 2012, Pusat Sumber Daya Geologi, Badan Geologi, telah melakukan pengeboran uji potensi GMB di daerah Lahat. Selama kegiatan pengeboran telah terjadi beberapa masalah teknis, salah satunya adalah terjadinya semburan gas.

\section{METODOLOGI}

Pengeboran sumur BML-1 sebagai sumur uji potensi GMB dilakukan dalam beberapa tahapan, yaitu: tahapan persiapan peralatan, persiapan lokasi, pelaksanaan pengeboran, dan pengambilan gas. Tahap persiapan peralatan meliputi persiapan bahan dan peralatan untuk pengeboran, yaitu: mesin bor, mesin pompa, bahan pembuat lumpur, bahan bakar, mata bor, suku cadang dan peralatan pendukung lainnya.

Tahapan persiapan lokasi dilakukan di wilayah yang telah di tentukan sebelumnya. Persiapan ini dilakukan untuk penempatan peralatan dan bahan yang akan digunakan dalam pengeboran. Lokasi pengeboran di tentukan berdasarkan pertimbanganpertimbangan sebagai berikut, yaitu lokasi daerah prospek, kondisi sosial masyarakat, aksesibilitas transportasi, ketersediaan air, dan lain sebagainya.

Tahapan pelaksanaan pengeboran dilakukan dengan pengambilan inti bor secara menerus (continous coring) dari permukaan sampai target kedalaman $500 \mathrm{~m}$. Pengeboran ini menggunakan dua seri pipa bor (rod), yaitu HQ (OD: 3.42") dan NQ (OD:2.75"), serta dilakukan pemasangan dua selubung (casing), yaitu HW (OD: 4.5") dan NW (OD:3.5") dengan kedalaman masing-masing disesuaikan dengan kondisi formasi lubang sumur.

Pelaksanaan pengambilan gas dilakukan dengan menggunakan Micro Gas Chromatography dan dianalisis di laboratorium mobil.

\section{KRONOLOGIPENGEBORAN}

Kontruksi lubang sumur BML-1 ini terdiri dari selubung HW dan selubung NW. Casing shoe HW diletakkan pada kedalaman 70,5 m, sedangkan casing shoe
NW diletakkan pada kedalaman $327 \mathrm{~m}$ dan kemudian dilanjutkan dengan open hole NQ sampai kedalaman akhir (TD) 504 m (Gambar 2).

Pada saat pengeboran mencapai kedalaman 295 - $307 \mathrm{~m}$, ada indikasi terjadi runtuhan karena tidak ada kemajuan pengeboran dan air pembilas tidak keluar. Pada saat mengangkat inner tube, terjadi core block yang diatasi dengan mengangkat rangkaian ke permukaan. Rod kembali dimasukkan sampai dasar lubang, dan dilakukan spulling lubang bor dari kedalaman 283-295 m.

Runtuhan terjadi lagi pada saat pengeboran mencapai kedalaman 307 - 319 $\mathrm{m}$, yang diindikasikan oleh adanya torsi dan putaran rod berat. Hal ini diatasi dengan mencabut rangkaian rod NQ sebanyak 5,5 batang. Setelah dilakukan spulling tanpa inner tube ternyata air pembilas tidak keluar, akan tetapi yang keluar adalah gas bertekanan saat sambungan water swivel dengan rod dibuka, yang menyebabkan water swivel terpental. Setelah itu kegiatan pengeboran dihentikan, dan lubang sumur didiamkan selama sekitar 12 jam untuk menunggu gas keluar sampai habis.

Berdasaran diskusi tim, untuk mengatasi runtuhan, kegiatan dilanjutkan dengan menambah rangkaian selubung NW dari 241-326 m, sesuai dengan hasil diskusi. Setelah itu kegiatan mengebor formasi dilanjutkan sampai dengan kedalaman 504 $\mathrm{m}$ tanpa ada hambatan lagi.

\section{HASIL DAN ANALISIS}

Sumur BML-1 telah menembus batuan dengan kedalaman akhir $504 \mathrm{~m}$. Ada 10 lapisan batubara telah diketahui dari sumur ini dengan ketebalan bervariasi antara 0,5 $10,3 \mathrm{~m}$. Telah terjadi keruntuhan pada saat pengeboran menembus lapisan batubara ke-9 (Gambar 2)

Dari sumur BML-1 diperoleh 60 conto batubara yang dimasukkan ke dalam canister. Dari hasil pengukuran kandungan gas tersebut, didapatkan nilai tertinggi kandungan gas dalam batubara terdapat pada kedalaman $200,00-200,50$ m sebesar 815 cc sedangkan nilai terendah pada kedalaman 178,25-178,75 m sebesar $51 \mathrm{cc}$ 
(Tabel 1).

Sedangkan hasil pengukuran nilai komposisi prosentase GMB di Muara Lawai didapatkan nilai prosentase $\mathrm{CH}_{4}$ tertinggi adalah di kedalaman 201,5 - 202,00 meter yaitu sebesar $86,75 \%$ sedangkan nilai prosentase terkecil adalah di kedalaman 395,00 - 395,50 m yaitu sebesar $0,86 \%$ (Tabel 2).

Dan hasil pengukuran sampel gas bertekanan (gas kick) (Gambar 3) didapatkan komposisi prosentase gas yakni $38,36 \% \mathrm{H}_{2}, 43,79 \% \mathrm{O}_{2}, 17,71 \% \mathrm{~N}_{2}, 0,03 \%$
$\mathrm{CH}_{4}$, dan $0,01 \% \mathrm{CO}_{2}$. Berdasarkan hasil tersebut dapat di analisis bahwa gas bertekanan yang keluar dari sumur BML-1 memiliki sifat yang mudah terbakar. Sehingga harus di antisipasi kemunculannya setiap melakukan pengeboran.

\section{DISKUSI}

Pada kegiatan pengeboran uji potensi GMB sumur BML-1, terdapat beberapa masalah yang mengganggu kelancaran proses pengeboran. Adapun masalah yang

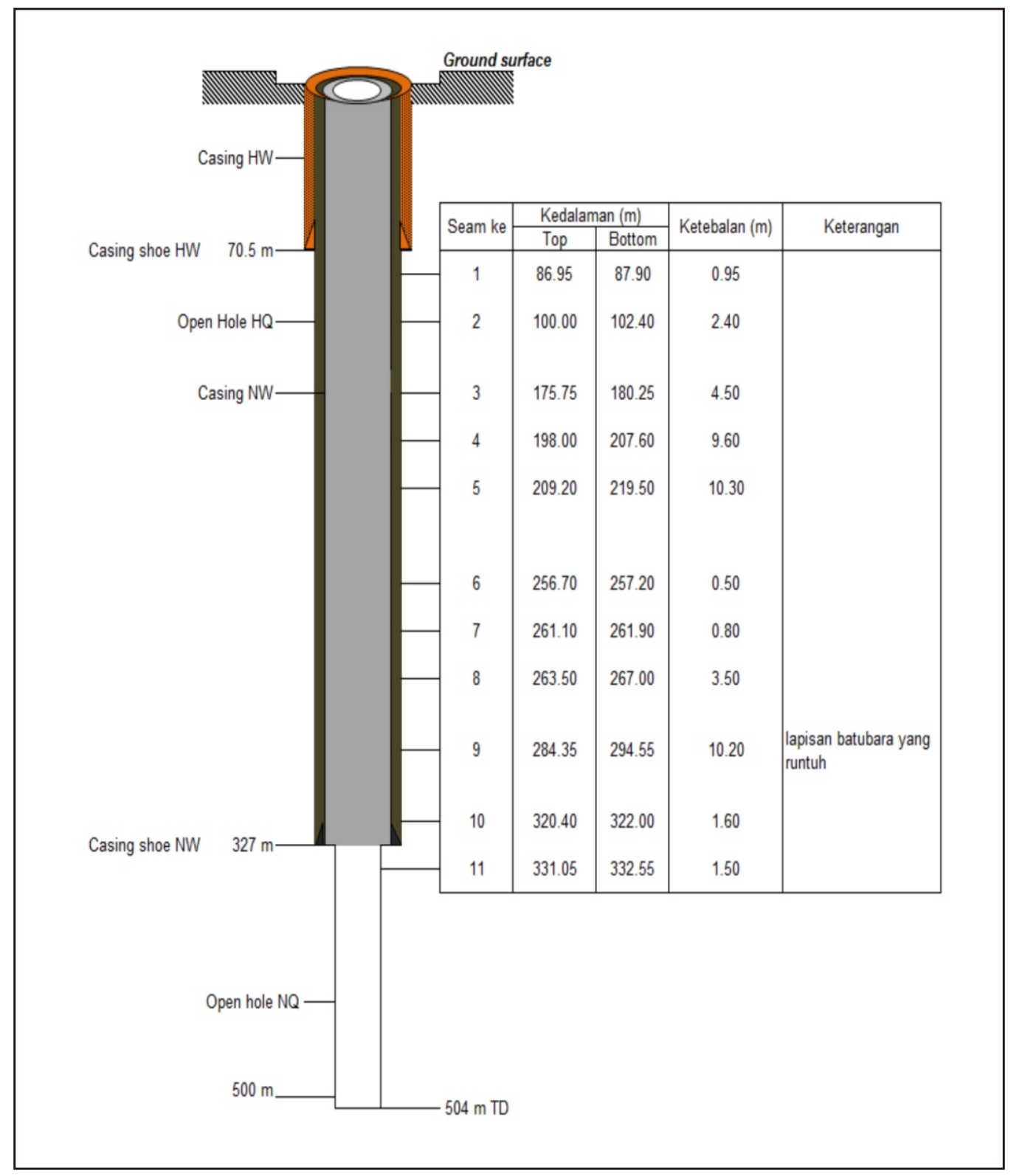

Gambar 2 Peta lokasi kegiatan pengeboran sumur BML-1 daerah Lahat, Propinsi Sumatera Selatan 
Tabel 1

Hasil Pengukuran Volume Gas

\begin{tabular}{|c|c|c|c|c|}
\hline \multirow{2}{*}{ No } & \multirow{2}{*}{$\begin{array}{l}\text { NOMOR } \\
\text { CANISTER }\end{array}$} & \multicolumn{2}{|c|}{ KEDALAMAN (m) } & \multirow{2}{*}{ TOTAL VOLUME Q2 (cc) } \\
\hline & & DARI & SAMPAI & \\
\hline 1 & 8 & 175,75 & 176,25 & 100,00 \\
\hline 2 & 9 & 176,25 & 176,75 & 57,00 \\
\hline 3 & 10 & 176,75 & 177,25 & 56,00 \\
\hline 4 & 11 & 177,25 & 177,75 & 97,00 \\
\hline 5 & 12 & 177,75 & 178,25 & 61,00 \\
\hline 6 & 13 & 178,25 & 178,75 & 51,00 \\
\hline 7 & 14 & 178,75 & 179,25 & 68,50 \\
\hline 8 & 15 & 179,25 & 179,75 & 76,50 \\
\hline 9 & 16 & 200,00 & 200,50 & 815,00 \\
\hline 10 & 17 & 201,00 & 201,50 & 659,00 \\
\hline 11 & 18 & 201,50 & 202,00 & 753,00 \\
\hline 12 & 19 & 202,00 & 202,50 & 814,50 \\
\hline 13 & 20 & 202,50 & 203,00 & 644,00 \\
\hline 14 & 21 & 203,00 & 203,50 & 492,00 \\
\hline 15 & 22 & 203,50 & 204,00 & 671,50 \\
\hline 16 & 1 & 204,50 & 205,00 & 539,00 \\
\hline 17 & 5 & 205,00 & 205,50 & 424,50 \\
\hline 18 & 23 & 205,50 & 206,00 & 244,00 \\
\hline 19 & 6 & 206,00 & 206,50 & 194,50 \\
\hline 20 & 4 & 206,50 & 207,00 & 314,50 \\
\hline 21 & 25 & 207,00 & 207,50 & 237,00 \\
\hline 22 & 7 & 209,20 & 209,70 & 404,50 \\
\hline 23 & 2 & 209,70 & 210,20 & 356,50 \\
\hline 24 & 35 & 210,20 & 210,70 & 282,00 \\
\hline 25 & 31 & 211,00 & 211,50 & 270,00 \\
\hline 26 & 33 & 211,50 & 212,00 & 293,50 \\
\hline 27 & 28 & 212,00 & 212,50 & 198,00 \\
\hline 28 & 34 & 213,00 & 213,40 & 250,50 \\
\hline 29 & 29 & 215,60 & 216,00 & 275,00 \\
\hline 30 & 26 & 216,00 & 216,50 & 369,50 \\
\hline 31 & 30 & 218,00 & 218,50 & 313,50 \\
\hline 32 & 27 & 221,00 & 221,50 & 223,00 \\
\hline 33 & 32 & 225,60 & 226,10 & 255,00 \\
\hline 34 & 41 & 226,10 & 226,60 & 205,50 \\
\hline 35 & 42 & 226,60 & 227,10 & 207,50 \\
\hline 36 & 43 & 261,10 & 261,60 & 472,50 \\
\hline 37 & 44 & 263,50 & 264,00 & 329,50 \\
\hline 38 & 36 & 264,00 & 264,50 & 513,50 \\
\hline 39 & 38 & 264,50 & 265,00 & 489,50 \\
\hline 40 & 40 & 265,00 & 265,50 & 431,50 \\
\hline 41 & 39 & 284,35 & 284,85 & 413,00 \\
\hline 42 & 45 & 284,85 & 285,35 & 303,00 \\
\hline 43 & 46 & 285,35 & 285,85 & 291,50 \\
\hline 44 & 47 & 285,85 & 286,35 & 444,50 \\
\hline
\end{tabular}




\begin{tabular}{|c|c|c|c|c|}
\hline \multirow{2}{*}{ No } & \multirow{2}{*}{$\begin{array}{c}\text { NOMOR } \\
\text { CANISTER }\end{array}$} & \multicolumn{2}{|c|}{ KEDALAMAN (m) } & \multirow{2}{*}{ TOTAL VOLUME Q2(cc) } \\
\cline { 3 - 5 } & & DARI & SAMPAI & \\
\hline $\mathbf{4 5}$ & 48 & 286,35 & 286,85 & 502,50 \\
\hline $\mathbf{4 6}$ & 49 & 286,85 & 287,35 & 676,50 \\
\hline $\mathbf{4 7}$ & 50 & 287,35 & 287,85 & 490,00 \\
\hline $\mathbf{4 8}$ & 51 & 290,00 & 290,50 & 524,50 \\
\hline $\mathbf{4 9}$ & 52 & 292,00 & 292,50 & 664,50 \\
\hline $\mathbf{5 0}$ & 53 & 292,50 & 293,00 & 494,50 \\
\hline $\mathbf{5 1}$ & 54 & 293,00 & 293,50 & 650,50 \\
\hline $\mathbf{5 2}$ & 56 & 320,40 & 320,90 & 365,50 \\
\hline $\mathbf{5 3}$ & 58 & 320,90 & 321,40 & 402,50 \\
\hline $\mathbf{5 4}$ & 59 & 331,50 & 332,00 & 90,00 \\
\hline $\mathbf{5 5}$ & 60 & 332,00 & 332,50 & 86,00 \\
\hline $\mathbf{5 6}$ & 61 & 332,50 & 333,00 & 89,50 \\
\hline $\mathbf{5 7}$ & 37 & 264,00 & 264,50 & 266,00 \\
\hline $\mathbf{5 8}$ & 62 & 388,50 & 389,00 & 68,50 \\
\hline $\mathbf{5 9}$ & 64 & 394,50 & 395,00 & 54,00 \\
\hline $\mathbf{6 0}$ & 65 & 395,00 & 395,50 & 69,00 \\
\hline
\end{tabular}

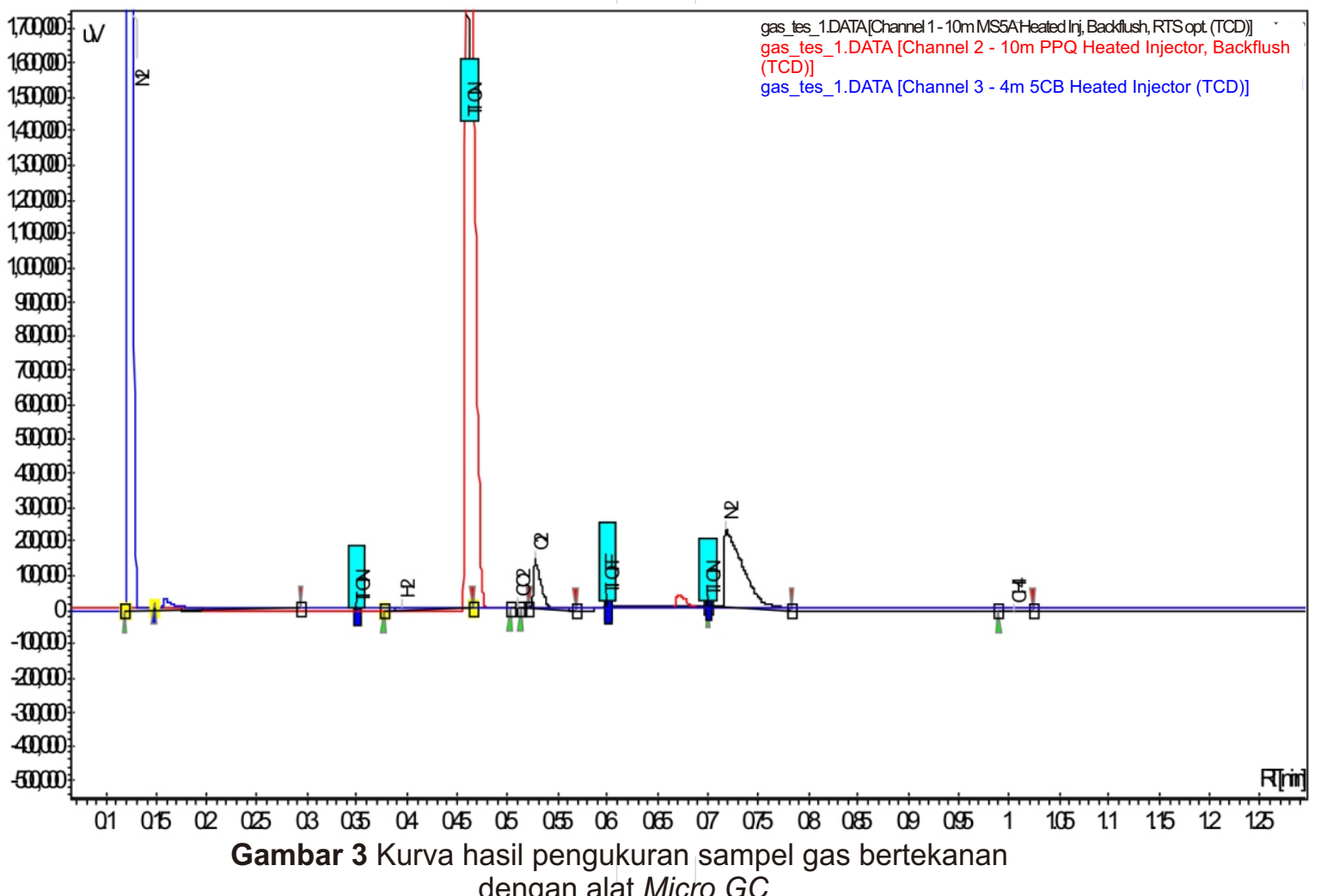

dengan alat Micro GC 
Tabel 2

Hasil Pengukuran Komposisi Prosentase Gas (\%)

\begin{tabular}{|c|c|c|c|c|c|c|c|c|c|c|}
\hline \multirow{2}{*}{ No } & \multirow{2}{*}{$\begin{array}{c}\text { NOMOR } \\
\text { CANISTER }\end{array}$} & \multirow{2}{*}{ KEDALAMAN (m) } & \multicolumn{7}{|c|}{ KOMPONEN GAS (\% vol) } & \multirow{2}{*}{ KETERANGAN } \\
\hline & & & $\mathbf{H}_{2}$ & $\mathrm{O}_{2}$ & $\mathbf{N}_{2}$ & $\mathrm{CH}_{4}$ & $\mathrm{CO}$ & $\mathrm{CO}_{2}$ & Total & \\
\hline 1 & 8 & $175,75-176,25$ & 0,00 & 28,23 & 65,18 & 6,14 & 0,00 & 0,43 & 99,98 & \\
\hline 2 & 9 & $176,25-176,75$ & NO SAMPLE & NO SAMPLE & NO SAMPLE & NO SAMPLE & NO SAMPLE & NO SAMPLE & 0,00 & VOLUME $=0$ \\
\hline 3 & 10 & $176,75-177,25$ & 0,00 & 34,06 & 64,46 & 1,14 & 0,00 & 0,33 & 99,99 & \\
\hline 4 & 11 & $177,25-177,75$ & 0,00 & 20,42 & 71,31 & 7,94 & 0,00 & 0,32 & 99,99 & \\
\hline 5 & 12 & $177,75-178,25$ & 0,00 & 21,53 & 69,39 & 8,72 & 0,00 & 0,35 & 99,99 & \\
\hline 6 & 13 & $178,25-178,75$ & 0,00 & 25,73 & 64,55 & 9,40 & 0,00 & 0,33 & 100,01 & \\
\hline 7 & 14 & $178,75-179,25$ & NO SAMPLE & NO SAMPLE & NO SAMPLE & NO SAMPLE & NO SAMPLE & NO SAMPLE & 0,00 & VOLUME $=0$ \\
\hline 8 & 15 & $179,25-179,75$ & 0,00 & 31,24 & 64,81 & 3,61 & 0,00 & 0,35 & 100,01 & \\
\hline 9 & 16 & $200,00-200,50$ & 4,15 & 0,25 & 11,06 & 80,43 & 0,54 & 3,58 & 100,01 & \\
\hline 10 & 17 & $201,00-201,50$ & 0,00 & 21,96 & 42,66 & 34,87 & 0,00 & 0,50 & 99,99 & \\
\hline 11 & 18 & $201,50-202,00$ & 0,00 & 0,33 & 11,16 & 86,75 & 0,00 & 1,76 & 100,00 & \\
\hline 12 & 19 & $202,00-202,50$ & 0,00 & 8,49 & 43,80 & 47,42 & 0,00 & 0,30 & 100,01 & \\
\hline 13 & 20 & $202,50-203,00$ & 0,00 & 26,31 & 46,69 & 26,64 & 0,00 & 0,36 & 100,00 & \\
\hline 14 & 21 & $203,00-203,50$ & 0,00 & 23,48 & 48,43 & 27,77 & 0,00 & 0,32 & 100,00 & \\
\hline 15 & 22 & $203,50-204,00$ & 0,00 & 13,91 & 37,31 & 48,18 & 0,00 & 1,78 & 101,18 & \\
\hline 16 & 1 & $204,50-205,00$ & 0,00 & 10,72 & 46,83 & 42,26 & 0,00 & 0,18 & 99,99 & \\
\hline 17 & 5 & $205,00-205,50$ & 1,03 & 3,34 & 59,40 & 36,06 & 0,00 & 0,18 & 100,01 & \\
\hline 18 & 23 & $205,50-206,00$ & NO SAMPLE & NO SAMPLE & NO SAMPLE & NO SAMPLE & NO SAMPLE & NO SAMPLE & 0,00 & VOLUME $=0$ \\
\hline 19 & 6 & $206,00-206,50$ & 0,00 & 29,91 & 47,02 & 22,77 & 0,00 & 0,30 & 100,00 & \\
\hline 20 & 4 & $206,50-207,00$ & NO SAMPLE & NO SAMPLE & NO SAMPLE & NO SAMPLE & NO SAMPLE & NO SAMPLE & 0,00 & VOLUME $=0$ \\
\hline 21 & 25 & $207,00-207,50$ & NO SAMPLE & NO SAMPLE & NO SAMPLE & NO SAMPLE & NO SAMPLE & NO SAMPLE & 0,00 & VOLUME $=0$ \\
\hline 22 & 7 & $209,20-209,70$ & 0,00 & 22,34 & 54,22 & 23,25 & 0,00 & 0,20 & 100,01 & \\
\hline 23 & 2 & $209,70-210,20$ & 0,00 & 22,99 & 55,07 & 21,65 & 0,00 & 0,29 & 100,00 & \\
\hline 24 & 35 & $210,20-210,70$ & 0,00 & 23,10 & 48,60 & 28,04 & 0,00 & 0,26 & 100,00 & \\
\hline 25 & 31 & $211,00-211,50$ & NO SAMPLE & NO SAMPLE & NO SAMPLE & NO SAMPLE & NO SAMPLE & NO SAMPLE & 0,00 & VOLUME $=0$ \\
\hline 26 & 33 & $211,50-212,00$ & 0,00 & 33,15 & 53,30 & 13,38 & 0,00 & 0,18 & 100,01 & \\
\hline 27 & 28 & $212,00-212,50$ & NO SAMPLE & NO SAMPLE & NO SAMPLE & NO SAMPLE & NO SAMPLE & NO SAMPLE & 0,00 & VOLUME $=0$ \\
\hline 28 & 34 & $213,00-213,50$ & 0,00 & 23,41 & 63,88 & 12,41 & 0,00 & 0,29 & 99,99 & \\
\hline 29 & 29 & $215,60-216,00$ & NO SAMPLE & NO SAMPLE & NO SAMPLE & NO SAMPLE & NO SAMPLE & NO SAMPLE & 0,00 & VOLUME $=0$ \\
\hline 30 & 26 & $216,00-216,50$ & 0,00 & 17,29 & 52,29 & 30,04 & 0,00 & 0,36 & 99,98 & \\
\hline 31 & 30 & $218,00-218,50$ & 0,00 & 26,63 & 50,31 & 22,71 & 0,00 & 0,36 & 100,01 & \\
\hline 32 & 27 & $221,00-221,50$ & 0,00 & 22,76 & 53,10 & 23,77 & 0,00 & 0,36 & 99,99 & \\
\hline 33 & 32 & $225,60-226,10$ & 0,00 & 12,00 & 76,28 & 11,49 & 0,00 & 0,23 & 100,00 & \\
\hline 34 & 41 & $226,10-226,60$ & 0,00 & 23,83 & 71,00 & 4,90 & 0,00 & 0,27 & 100,00 & \\
\hline 35 & 42 & $226,60-227,10$ & 0,00 & 15,88 & 67,67 & 16,13 & 0,00 & 0,33 & 100,01 & \\
\hline 36 & 43 & $261,10-261,60$ & 1,54 & 5,92 & 51,02 & 41,18 & 0,00 & 0,34 & 100,00 & \\
\hline 37 & 44 & $263,50-264,00$ & NO SAMPLE & NO SAMPLE & NO SAMPLE & NO SAMPLE & NO SAMPLE & NO SAMPLE & 0,00 & VOLUME $=0$ \\
\hline 38 & 36 & $264,00-264,50$ & 0,00 & 21,58 & 58,20 & 19,98 & 0,00 & 0,23 & 99,99 & \\
\hline 39 & 38 & $264,50-265,00$ & 0,00 & 13,17 & 44,51 & 42,04 & 0,00 & 0,28 & 100,00 & \\
\hline 40 & 40 & $265,00-265,50$ & 0,00 & 12,39 & 68,47 & 18,84 & 0,00 & 0,30 & 100,00 & \\
\hline 41 & 39 & $284,35-284,85$ & 0,97 & 20,55 & 47,19 & 28,93 & 0,70 & 1,66 & 100,00 & \\
\hline 42 & 45 & $284,85-285,35$ & NO SAMPLE & NO SAMPLE & NO SAMPLE & NO SAMPLE & NO SAMPLE & NO SAMPLE & 0,00 & VOLUME $=0$ \\
\hline 43 & 46 & $285,35-285,85$ & NO SAMPLE & NO SAMPLE & NO SAMPLE & NO SAMPLE & NO SAMPLE & NO SAMPLE & 0,00 & VOLUME $=0$ \\
\hline 44 & 47 & $285,85-286,35$ & NO SAMPLE & NO SAMPLE & NO SAMPLE & NO SAMPLE & NO SAMPLE & NO SAMPLE & 0,00 & VOLUME $=0$ \\
\hline 45 & 48 & $286,35-286,85$ & NO SAMPLE & NO SAMPLE & NO SAMPLE & NO SAMPLE & NO SAMPLE & NO SAMPLE & 0,00 & VOLUME $=0$ \\
\hline
\end{tabular}


tabel 2 lanjutan

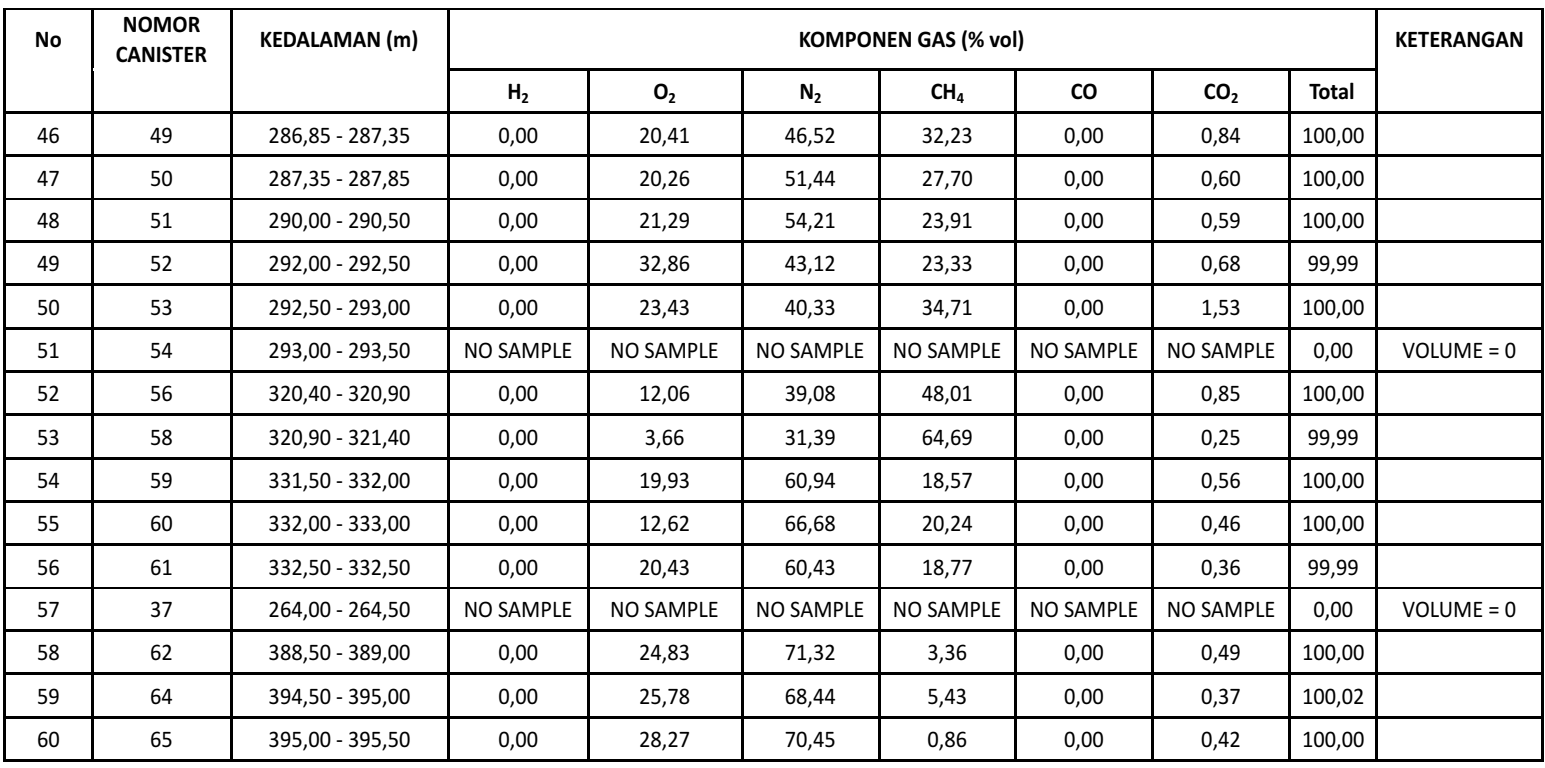

dianggap serius adalah keluarnya gas bertekanan pada kedalaman $319 \mathrm{~m}$. Namun demikian kegiatan pengeboran tetap harus dilanjutkan mengingat target kedalaman adalah $500 \mathrm{~m}$ dan kondisi gas tidak keluar lagi setelah lubang sumur didiamkan selama 12 jam.

Setelah mengamati kronologi pengeboran dari kedalaman 283 - $319 \mathrm{~m}$, diperkirakan gas bertekanan keluar akibat dari runtuhnya lapisan batubara dengan ketebalan 10 m (kedalaman 284,35 - 294,55 $\mathrm{m})$. Keluarnya gas diawali dengan kondisi lumpur yang sudah jenuh dengan serbuk bor (cutting), diikuti oleh tidak majunya pipa bor, karena adanya jepitan dari runtuhan batu bara, kemudian air pembilas tidak keluar (loss circulation), dan setelah pipa diangkat 6 batang gas mulai keluar.

Cara menanggulangi kejadian tersebut dengan memasukkan bola-bola bentonit ke dalam lubang sumur dan didiamkan sekitar 12 jam guna mengetahui apakah gas masih keluar secara kontinyu atau tidak. Setelah gas berhenti keluar, fokus pemecahan masalah pada runtuhnya lubang, yaitu dengan pemasangan selubung NW sampai dengan kedalaman $327 \mathrm{~m}$.

Dalam kegiatan pengeboran, tidak akan luput dari permasalahan yang dapat mengurangi kelancaran atau bahkan dapat menghentikan kegiatan pengeboran tersebut sebelum waktunya. Oleh karena itu diperlukan perencanaan yang matang (drilling optimation) sebelum melakukan pengeboran, agar dapat meminimalisasikan permasalahan yang akan menghambat proses pengeboran.

\section{KESIMPULAN}

Pengeboran sumur BML-01 telah menembus batuan sedimen dengan sisipan lapisan batubara dengan kedalaman akhir terukur $504 \mathrm{~m}$. Dalam pengeboran ini ditemukan 11 lapisan batubara dengan ketebalan bervariasi antara 0,5 m-10m .

Gas yang keluar (gas kick) di kedalaman $319 \mathrm{~m}$ pada sumur BML-01 diduga merupakan efek dari runtuhnya lapisan batubara ke-9 dengan ketebalan $10 \mathrm{~m}$.

\section{UCAPAN TERIMAKASIH}

Ucapan terima kasih disampaikan kepada Ir. Kasbani M.Sc. atas masukan, koreksi dan saran-sarannya. Juga kepada Tim Kegiatan GMB Lahat, sehingga makalah ini dapat diselesaikan.

\section{DAFTAR PUSTAKA}

Anonim, 2012a. Hasil Kegiatan Pengukuran Gas CBM Di Daerah Muara Lawai Kecamatan Merapi Timur, Kabupaten Lahat, Provinsi Sumatera Selatan, Pusat Sumber Daya Geologi, Bandung. 


\section{MAKALAH ILMIAH}

Anonim, 2012b, Pengeboran Potensi CBM Daerah Muara Lawai Sumur BML-1, Kabupaten Lahat,

Provinsi Sumatera Selatan, Laporan, Pusat Sumber Daya Geologi, Bandung.

Cahyono, E. B., 2011, Pengeboran Dalam Batubara dan Pengukuran Kandungan Gas Metan Batubara Di Daerah Bukit Sibantar, Kecamatan Talawi. Provinsi Sumatera Barat, tidak dipublikasikan, Pusat Sumber Daya Geologi, Bandung.

Ibrahim, D., Wibowo S. A., 2009, Pengeboran Dalam Batubara Dan Pengukuran Kandungan Gas Di Daerah Kabupaten Muaraenim Provinsi Sumatera Selatan, Prosiding Kolokium, Pusat Sumber Daya Geologi, Bandung.

Kartasumantri, N. S., 1998, Eksplorasi Endapan Batubara Di Daerah Bungamas, Kabupaten Lahat Propinsi Sumatera Selatan, Prosiding Kolokium, Direktorat Sumber Daya Mineral, Bandung.

Pujobroto, A., 1999, Pengkajian Cekungan Batubara Di Daerah Muaralakitan, Kabupaten Musirawas, Provinsi Sumatera Selatan, Prosiding Kolokium, Direktorat Sumber Daya Mineral, Bandung.

http://www.bpmigas.go.id/blog/2012/04/09/kesalahan-persepsi-dan-potensi-energi-di-indonesia/. Kesalahan persepsidan potensi energi di indonesia.

http://www.investor.co.id/energy/eksplorasi-cbm-dapat-perlakuan-istimewa/34313. Eksplorasi cbm dapat perlakuan istimewa. 